\title{
Lipid Composition of Three Bermudagrasses in Response to Chilling Stress
}

\author{
Charles Fontanier, Justin Quetone Moss, and Lakshmy Gopinath \\ Department of Horticulture and Landscape Architecture, Oklahoma State University, 358 Agricul- \\ tural Hall, Stillwater, OK 74078 \\ Carla Goad \\ Department of Statistics, Oklahoma State University, 301 MSCS Building, Stillwater, OK 74078
}

\author{
Kemin Su \\ Department of Horticulture and Landscape Architecture, Oklahoma State University, 358 Agricul- \\ tural Hall, Stillwater, OK 74078
}
Yanqi Wu
Department of Plant and Soil Sciences, Oklahoma State University, 371 Agricultural Hall, Stillwater, OK 74078

\begin{abstract}
AdDitional INDEX words. Cynodon, digalactosyldiacylglycerol, double bond index, electrospray ionization tandem mass spectrometry, fall color retention, monogalactosyldiacylglycerol

Abstract. Cell and plastid membranes play a critical role in plant response to chilling stress. Fall color retention (chilling tolerance) of bermudagrass (Cynodon sp.) is known to vary with cultivar and management practices. A growth chamber study was conducted to characterize the lipid composition of three bermudagrasses in response to chilling stress. The grasses selected were 'Tahoma 31' (chilling-sensitive) and 'Tifway' (chilling-tolerant) interspecific hybrid bermudagrass $(C$. dactylon $\times C$. transvaalensis) and 'Celebration' common bermudagrass $(C$. dactylon), which served as an internal standard. Plants were subjected to simulated fall conditions defined as an $8 / 2{ }^{\circ} \mathrm{C}$ (day/night) temperature regime with 10-hour photoperiod and evaluated for chilling response for 42 days before allowing plants to enter an apparent dormancy. Plant leaves were sampled for lipidomics analysis at 0,14 , and 42 days of chilling treatment (DOT) and again after 40 days of recovery from dormancy (during which temperatures were adjusted to mimic average spring conditions for Oklahoma). 'Tifway' demonstrated the lowest electrolyte leakage (EL) and visual discoloration at 42 DOT, while 'Tahoma 31' had the greatest EL and discoloration on the same date, and 'Celebration' was intermediate of the two. Prolonged exposure to chilling stress generally increased digalactosyldiacylglycerol and phosphatidylcholine (PC) content and decreased monogalactosyldiacylglycerol (MGDG) content, with 'Tahoma 31' showing the greatest increase in PC and decrease in MGDG. The double bond index, an indicator of fatty acid unsaturation, was greatest in 'Tifway' at 42 DOT. Each cultivar increased in fatty acid unsaturation, with Tifway demonstrating the greatest increase in MGDG unsaturation. Multivariate discriminant analysis identified six individual lipid species that contributed most to the cultivar response to chilling. These findings suggest unsaturation level of plastid lipids, particularly MGDG, is important for chilling tolerance and therefore fall color retention of bermudagrass. Furthermore, this study provides evidence that chilling tolerance can be negatively associated with freezing tolerance in bermudagrass.
\end{abstract}

Chilling injury (CI) can occur in susceptible turfgrasses, such as bermudagrass (Cynodon sp.), as a result of nonfreezing low temperature stress. Bermudagrass is a warm-season turfgrass predominantly grown in the southern and transition zone regions of the United States, where CI can be characterized by

Received for publication 29 Aug. 2019. Accepted for publication 3 Dec. 2019. Published online 21 January 2020

Funding for this project was provided by the Oklahoma Agricultural Experiment Station, U.S. Department of Agriculture, National Institute of Food and Agriculture Hatch Project (OKL02923), and the Wayne W. and Jean Huffine Professorship in Turfgrass Science. The lipid analyses described in this work were performed at the Kansas Lipidomics Research Center Analytical Laboratory in Manhattan, KS. Instrument acquisition and lipidomics method development was supported by the National Science Foundation (EPS 0236913, MCB 1413036, MCB 0920663, DBI 0521587, and DBI1228622), Kansas Technology Enterprise Corporation, K-IDeA Networks of Biomedical Research Excellence (INBRE) of the National Institute of Health (P20GM103418), and Kansas State University.

C.F. is the corresponding author. E-mail: charles.fontanier@okstate.edu.

This is an open access article distributed under the CC BY-NC-ND license (https://creativecommons.org/licenses/by-nc-nd/4.0/). loss of chlorophyll and a resulting off-color appearance associated with a decrease in photosynthetic activity (White and Schmidt, 1989). For fall-season sports, maintenance of aesthetic quality associated with chilling tolerance is important.

During chilling stress, the functionality and survival of a plant cell depends on the integrity of membranes. The chloroplast is typically the first location within the cell to incur CI (Kimball and Salisbury, 1973). The thylakoid membrane system is primarily composed of galactolipids: monogalactosyldiacylglycerol (MGDG) and digalactosyldiacylglycerol (DGDG) (Douce and Joyard, 1990). In contrast, the plasma membrane primarily consists of phospholipids, including phosphatidylcholines (PC), phosphatidylethanolamines (PE), phosphatidylglycerols (PG), phosphatidylinositols (PI), phosphatidylserines (PS), phosphatidic acids (PA), and glycerolipids. Injury to membranes during chilling stress occurs as the lipid bilayer shifts from a liquid crystalline state to gel crystalline state (Raison and Orr, 1990). This solidification of membrane lipids at low temperature is followed by contraction and the formation of cracks (Lyons and Raison, 1970). 
Plants undergo physiological changes in response to low nonfreezing temperatures. This process is termed "cold acclimation" and can increase the survivability of cells under subsequent freezing stress. For warm-season turfgrasses that undergo a seasonal dormancy, freezing tolerance can be more akin to winter survivability and is hereafter defined as the ability of nodes within rhizomes and/or stolons to survive winter low temperatures and resume normal growth in the spring. The importance of cold acclimation for turfgrass freezing tolerance has been reported to include shifts in osmotic protectants, protein synthesis, antioxidant production, and fatty acid saturation (Munshaw et al., 2006; Zhang et al., 2006). Samala et al. (1998) reported greater desaturation of fatty acids in crown tissue after $12 \mathrm{~d}$ of cold acclimation for the freezingtolerant cultivar Midiron interspecific hybrid bermudagrass [ $C$. dactylon $\times C$. transvaalensis) as compared with the freezingsensitive cultivar U-3 common bermudagrass ( $C$. dactylon). Cold acclimation is essentially analogous to chilling stress, and plant physiological changes that contribute to enhanced freezing tolerance may have different effects on chilling tolerance.

White and Schmidt (1989) reported differences in chilling tolerance between 'Midiron' and 'Tifgreen' interspecific hybrid bermudagrass. The same authors concluded that chilling influenced carbohydrate distribution and induced loss of chlorophyll, which contributed to photosynthetic inactivity; and that the more chilling-tolerant cultivar (Midiron) was able to recover from acute $\mathrm{CI}$ by resuming normal processes quickly.

Reports from the National Turfgrass Evaluation Program (NTEP) show that 'Tifway' bermudagrass has repeatedly performed well in regards to a "frost tolerance rating"-which can be considered comparable to fall color retention or chilling tolerance (NTEP, 1997, 2014). Interestingly, turfgrasses demonstrating poor chilling tolerance have, in some cases, been associated with superior freezing tolerance and early postdormancy regrowth (Munshaw et al., 2006; NTEP, 2014). The underlying mechanism for these responses to chilling is uncertain, but membrane integrity is a critical aspect of chilling and freezing tolerance that may be involved. A better understanding of these processes may contribute to more efficient selection and improvement of germplasm for the chilling tolerance trait.

The objectives of the study were to 1) quantify membrane lipid composition in leaves of three bermudagrasses under prolonged chilling stress and 2) identify relationships between lipid composition and apparent chilling tolerance in bermudagrass.

\section{Materials and Methods}

Establishment. The experiment was conducted using 'Tifway' and 'Tahoma 31' interspecific hybrid bermudagrass and 'Celebration' common bermudagrass. These cultivars were selected to represent an apparent chilling-tolerant plant (Tifway), chilling-sensitive plant (Tahoma 31), and an internal standard (Celebration) that had been used in a previous lipidomics analysis ( $\mathrm{Su}$ et al., 2013). Plastic pots $(21 \mathrm{~cm}$ diameter $\times 21$ $\mathrm{cm}$ deep) were filled with a 1:1 (v/v) mixture of sand and bagged topsoil (Oldcastle APG, Atlanta, GA), and plants were established 5 Aug. 2014 from washed plugs collected from plant materials previously maintained at the Oklahoma State University Horticultural Research Greenhouses in Stillwater.

After planting, pots were maintained in a greenhouse for 3 months. Average day/night air temperatures were maintained at
$30 / 20{ }^{\circ} \mathrm{C}$ (day/night) and supplemental light was applied using incandescent lamps under a 14-h photoperiod. Grasses were clipped weekly at $5 \mathrm{~cm}$ and watered twice per week with fertilizer solution at $0.25 \mathrm{~g} \cdot \mathrm{L}^{-1} \mathrm{~N}$ of $20 \mathrm{~N}-8.7 \mathrm{P}-16.6 \mathrm{~K}$ watersoluble fertilizer (Jack's Professional; J.R. Peters, Allentown, PA). On 4 Nov. 2014, pots were transferred to a growth chamber (PGW-36; Conviron Controlled Environments, Winnipeg, MB, Canada) at the Oklahoma State University Controlled Environmental Research Laboratory and acclimated for 3 weeks at optimal growing conditions $\left(30 / 25^{\circ} \mathrm{C}\right.$; 14-h light/ 10-h darkness) and a photosynthetic photon flux density of 680 $\mu \mathrm{mol} \cdot \mathrm{m}^{-2} \cdot \mathrm{s}^{-1}$ during the daylight period. Turfgrasses were clipped once per week at $5 \mathrm{~cm}$ and irrigated every $3 \mathrm{~d}$ to prevent drought stress. Turfgrasses were fertilized every $6 \mathrm{~d}$ with the previously described fertilizer solution at a rate of 16 $\mathrm{kg} \cdot \mathrm{ha}^{-1} \mathrm{~N}$.

Chilling treatment. After the acclimation period, pots were subjected to a chilling stress on defined as $8 / 2{ }^{\circ} \mathrm{C}$ (day/night) with 10-h photoperiod. Chilling stress was implemented from 25 Nov. 2014 to 7 Jan. 2015 (42 d) to assess cultivar response to short-term and extended chilling stress. Subsequently, chilling was maintained until 10 Sept. 2015 (35 weeks) to induce an apparent dormancy in all pots. During this period, pots resulted in a complete loss of green color in aerial shoots. After which, the temperature was gradually increased over a 40-d period that mimicked local spring conditions (Oklahoma Mesonet, 2015): $14 \mathrm{~d}$ under $17 / 3{ }^{\circ} \mathrm{C}, 7 \mathrm{~d}$ under 22/8 ${ }^{\circ} \mathrm{C}, 19 \mathrm{~d}$ under $27 / 14{ }^{\circ} \mathrm{C}$ (10-h photoperiod for each temperature regime).

Measurements. Discrete measurements of visual injury, leaf chlorophyll content, leaf electrolyte leakage (EL), and lipid composition were made at 0,14 , and $42 \mathrm{~d}$ of chilling treatment (DOT) and again after $40 \mathrm{~d}$ of recovery (DOR), which corresponded to 25 Nov. 2014, 10 Dec. 2014, 7 Jan. 2015, and 20 Oct. 2015. Visual injury was defined as loss of green color and was collected on a percentage basis where all plants had $0 \%$ leaf discoloration at 0 DOT and ratings were assessed on increments of $5 \%$ up to $100 \%$ if completely dormant. Percent green coverage was also estimated using a $0 \%$ to $100 \%$ scale and 5\% increment on 2 Oct. 2015 (22 DOR) to characterize post-dormancy regrowth rates. Chlorophyll content was measured in-situ for six similarly aged (second or third position) green leaves using a handheld chlorophyll meter (CCM-300; Opti-Sciences, Hudson, NH).

Cell membrane stability was estimated using EL. Five green leaves of similar age (second or third position) were sampled from each pot. Leaves were cut into $2-\mathrm{cm}$ segments and rinsed three times with distilled deionized water. Segments were placed in a separate test tube for each pot and filled with 20 $\mathrm{mL}$ distilled deionized water. Test tubes were placed on a shaker at $120 \mathrm{rpm}$ for $24 \mathrm{~h}$ to dissolve any electrolytes leaking from cells. The solution conductivity $(C 1)$ was measured with a conductivity meter. Subsequently, leaves were autoclaved at $140{ }^{\circ} \mathrm{C}$ for $20 \mathrm{~min}$ to destroy the cell membranes, test tubes were shaken for $24 \mathrm{~h}$ at room temperature to dissolve all the total electrolytes leaked from cells, and the conductivity $(C 2)$ was measured again. The percent electrolyte leakage was calculated as $\mathrm{EL}=C 1 / C 2 \times 100$, with a lower EL indicating greater resistance to chilling stress.

Lipids were extracted according to the procedure of Devaiah et al. (2006) with minor modifications as previously reported by $\mathrm{Su}$ et al. (2009). Briefly, 15 fully expanded, green leaves of 
about the same age (second or third position) were collected from each pot. Leaves were quickly immersed in $3 \mathrm{~mL}$ isopropanol with $0.01 \%$ butylated hydroxytoluene at $75{ }^{\circ} \mathrm{C}$ to inactivate lipolytic activity. After $15 \mathrm{~min}, 1.5 \mathrm{~mL}$ chloroform and $0.6 \mathrm{~mL}$ water were added, and the tubes were shaken for $1 \mathrm{~h}$. Thereafter, the extract was removed and replaced with chloroform/methanol $(2: 1)$ with $0.01 \%$ butylated hydroxytoluene, and the tubes were shaken for $30 \mathrm{~min}$. The latter procedure was repeated five times until the leaves of every sample appeared white. The remaining leaf material was then dried overnight at $105^{\circ} \mathrm{C}$ and weighed. The combined extracts were washed once with $1 \mathrm{~mL} 1 \mathrm{M} \mathrm{KCl}$ and once with $2 \mathrm{~mL}$ water, evaporated under $\mathrm{N}$, and filled with $\mathrm{N}$ gas. The lipid extracts in glass tubes were shipped on dry ice to the Kansas Lipidomics Research Center (KLRC) at Kansas State University (Manhattan). Lipid composition was analyzed by the electrospray ionization tandem mass spectrometry (ESI-MS/MS) in the KLRC analytical laboratory according to the methods of Devaiah et al. (2006) and Welti et al. (2002). The concentration of MGDG, DGDG, PG, PA, PC, PE, PI, and PS was quantified and reported on a percent mole basis. Double-bond indices (DBI) were calculated using Eq. [1],

$$
\mathrm{DBI}=\sum_{i=1}^{n}\left(N_{i} * \operatorname{mol} \%_{i}\right) / 100
$$

where $n$ is the total number of lipid species measured, $N$ is the number of double bonds in the $i$ th lipid species, and mol $\%$ refers to the percentage (on a mol basis) of the $i$ th lipid species compared with the total lipids in the sample (Zhang et al., 2009).

Statistical analysis. The experiment was conducted as a completely randomized design with five replications (or pots) of each of three cultivars; 15 pots total. There were four repeated measures $(0,14,42$ DOT, and 40 DOR) obtained on each pot for each cultivar. Due to the unequal spacing of these repeated measures, an unstructured covariance matrix was used to model the response variables over time. Electrolyte leakage, chlorophyll, lipid content, DBI, and percent injury data were analyzed using generalized linear mixed models (GLIMMIX) methods for repeated measures (SAS version 9.4 for Windows; SAS Institute, Cary, NC). Means for significant effects were separated using Fisher's unadjusted $t$ tests. In the lipid profile, a stepwise discriminant analysis was performed for the classification of a priori groups defined by genotype, time of sampling, or their interaction (SAS version 9.4 for Windows). This method has been used previously as a form of data reduction to classify turfgrass species by morphological traits (Fontanier and Steinke, 2017). Patterns in the relationships among lipid classes were evaluated using linear correlation analysis (SPSS version 23.0 for Windows; IBM Corp., Armonk, NY). All tests were performed at the $P \leq 0.05$ level of significance.

\section{Results and Discussion}

Chilling TOlerance AND POST-DORMANCY REgRowth. For each stress indicator (i.e., visual injury, electrolyte leakage, and chlorophyll content), the cultivar by date interaction was significant. For each cultivar, visual injury was evident but modest (17\% discolored) by 14 DOT and increased in the subsequent date ( $52 \%$ discolored), suggesting the experimental conditions were adequately applying chilling stress to plants
(Fig. 1). 'Tahoma 31' (chilling sensitive) demonstrated the greatest visual injury at 42 DOT. Chlorophyll content and EL followed similar patterns with significantly less chlorophyll and greater EL in 'Tahoma 31' at 42 DOT as compared with other cultivars (Figs. 2 and 3). The lack of difference in chlorophyll content or EL at 14 DOT was somewhat surprising but might suggest a degree of tolerance among all cultivars. In comparison, White and Schmidt (1989) reported a 25\% decrease in chlorophyll content in 'Tifgreen' (chilling sensitive) after just $4 \mathrm{~d}$ under chilling treatment $\left(10 / 7{ }^{\circ} \mathrm{C}\right.$ day/night $)$, while 'Midiron' (chilling tolerant) showed no decrease after the same time period. Zhang et al. (2008) reported greater EL for 'Tifway' than 'Patriot' after $21 \mathrm{~d}$ of cold acclimation. In contrast, NTEP reported 'Tifway' has superior frost tolerance to 'Patriot' under field conditions (NTEP, 2013). These discrepancies suggest short-term chilling response (14-21 d) may not be indicative of real-world chilling tolerance.

After chilling stress was removed, 'Tahoma 31' recovered from apparent dormancy quickly, achieving greater than 75\% green cover (visual observation) in each of five replicates at 22 DOR (data not presented). In contrast, 'Tifway' and 'Celebration' achieved $75 \%$ cover in only three and one replicates, respectively. The superior post-dormancy regrowth observed for 'Tahoma 31' is in agreement with previous field observations (NTEP, 2014). Schiavon et al. (2016) associated bermudagrass green-up rates with water-soluble carbohydrate content of stem tissues. White and Schmidt (1989) similarly attributed faster recovery from CI to greater reducing and nonreducing sugar content within stolons and rhizomes of 'Midiron'.

Although the present study did not directly assess the freezing tolerance of the selected bermudagrasses, winter kill ratings averaged across two NTEP trial locations (Indiana and Kentucky) were $14.5 \%$ for 'Tahoma 31 ' in comparison with 98.5\% and $98.0 \%$ for 'Tifway' and 'Celebration', respectively, suggesting greater freezing tolerance for 'Tahoma 31' over the other two cultivars (NTEP, 2014). 'Midiron' has been among the most studied bermudagrass for cold acclimation and freezing tolerance, with several studies describing it as either chilling tolerant or freezing tolerant (Anderson et al., 1993; Gatschet et al., 1994; Munshaw et al., 2006; White and Schmidt, 1989). Certainly, the physiological attributes that contribute chilling tolerance (e.g., membrane lipid desaturation) are also considered important for freezing tolerance. However, our study supports the hypothesis that a freezingtolerant cultivar can also be chilling sensitive (Munshaw et al., 2006). It is possible this occurs because some aspects of low temperature acclimation are more critical for chilling tolerance and others for freezing tolerance, or that cold acclimation may affect different organs uniquely for each genotype. For example, in their study quantifying the reducing and nonreducing sugar concentrations in two bermudagrass cultivars varying in chilling tolerance, White and Schmidt (1989) reported Midiron (freezing-tolerant) as having greater amounts of reducing and nonreducing sugars in stolons and rhizomes as compared with Tifgreen (freezing-sensitive). In contrast, the same study demonstrated the reverse relationship for leaves.

LiPIDS UNIVARIATE ANALYSIS. Galactolipids (MGDG and DGDG) averaged $89 \%$ of the total lipids across all cultivars and sampling dates (Table 1). This was within $3 \%$ of the values reported by $\mathrm{Su}$ et al. (2013) using a similar lipidomics methodology. Between the galactolipids measured, MGDG content (mol \%) typically ranged between 2- and 3-fold that of DGDG. 


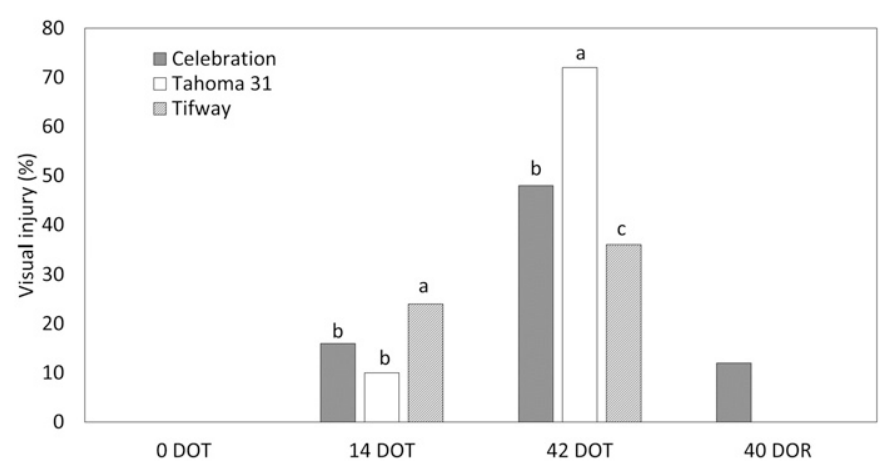

Fig. 1. Visual injury scores $(0 \%$ to $100 \%)$ for 'Tifway', 'Celebration', and 'Tahoma 31 ' bermudagrass after exposure to 0,14 , and $42 \mathrm{~d}$ of chilling treatment (DOT) at $8 / 2{ }^{\circ} \mathrm{C}$ and $40 \mathrm{~d}$ of recovery (DOR) after $14 \mathrm{~d}$ under $17 / 3{ }^{\circ} \mathrm{C}, 7 \mathrm{~d}$ under $22 / 8{ }^{\circ} \mathrm{C}$, and $19 \mathrm{~d}$ under $27 / 14{ }^{\circ} \mathrm{C}$. Values represent the mean of five pots per cultivar. Within each date, means assigned similar lowercase letters are not significantly different $(P \leq 0.05, \mathrm{~N}=5)$ according to Fisher's unadjusted $t$ test.

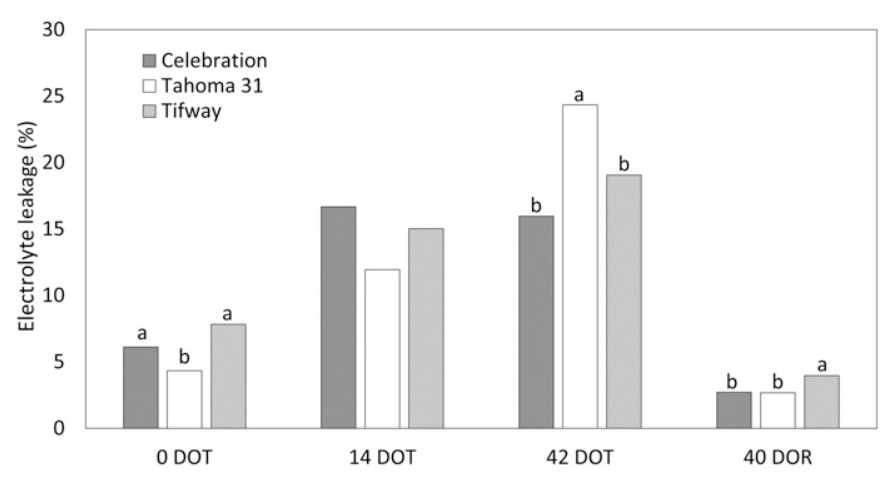

Fig. 2. Leaf electrolyte leakage for 'Tifway', 'Celebration', and 'Tahoma 31' bermudagrass after exposure to 0,14 , and $42 \mathrm{~d}$ of chilling treatment (DOT) at $8 / 2{ }^{\circ} \mathrm{C}$ and $40 \mathrm{~d}$ of recovery (DOR) after $14 \mathrm{~d}$ under $17 / 3{ }^{\circ} \mathrm{C}, 7 \mathrm{~d}$ under $22 /$ $8^{\circ} \mathrm{C}$, and $19 \mathrm{~d}$ under $27 / 14^{\circ} \mathrm{C}$. Values represent the mean of five leaves from each of five pots per cultivar. Within each date, means assigned similar lowercase letters are not significantly different $(P \leq 0.05, \mathrm{~N}=5)$ according to Fisher's unadjusted $t$ test.

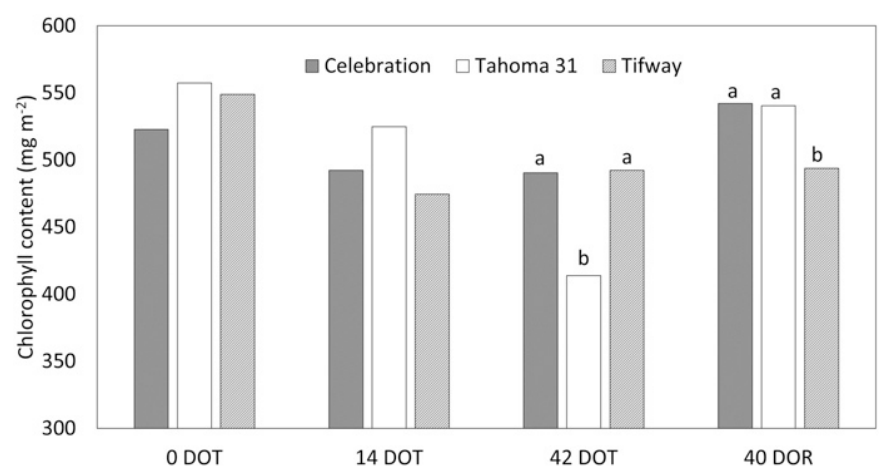

Fig. 3. Leaf chlorophyll content measured in situ using a chlorophyll meter for 'Tifway', 'Celebration', and 'Tahoma $31^{\prime}$ ' bermudagrass after exposure to 0 , 14 , and $42 \mathrm{~d}$ of chilling treatment (DOT) at $8 / 2{ }^{\circ} \mathrm{C}$ and $40 \mathrm{~d}$ of recovery (DOR) after $14 \mathrm{~d}$ under $17 / 3{ }^{\circ} \mathrm{C}, 7 \mathrm{~d}$ under $22 / 8{ }^{\circ} \mathrm{C}$, and $19 \mathrm{~d}$ under $27 / 14{ }^{\circ} \mathrm{C}$. Values represent the mean of six leaves from each of five pots per cultivar. Within each date, means assigned similar lowercase letters are not significantly different ( $P \leq 0.05, \mathrm{~N}=5$ ) according to Fisher's unadjusted $t$ test.
After exposure to chilling stress, leaf MGDG content decreased while DGDG content increased (Table 2). This inverse response in galactolipid composition has been reported previously by Uemura and Steponkus (1997) studying cereal rye (Secale cereale) chloroplasts and could be mediated through the conversion of MGDG to DGDG by DGDG synthase (Boudière et al., 2014). 'Tahoma 31' (chilling sensitive) contained the lowest MGDG at 14 and 42 DOT, while also showing the largest decrease from 0 to 42 DOT among the three cultivars (Table 1). In contrast, 'Tifway' (chilling tolerant) demonstrated a greater MGDG content at 42 DOT despite having a similar concentration to 'Tahoma 31' at 0 DOT. Because DGDG is a large polar head group that contributes to greater bilayer formation and improved membrane stability, it was expected that the more chilling-tolerant cultivar would have declined in the MGDG to DGDG ratio to a greater extent than the chilling-sensitive cultivar (Uemura and Steponkus, 1997). The opposite finding suggests other aspects of lipid membranes could be more important to chilling tolerance of 'Tifway' than simply the MGDG to DGDG ratio. Bruce (1998), in a review of lipids and protein transport, suggests the increased curvature stress associated with the nonlamellar phase may be beneficial to several biochemical processes. That is, lipid composition seeks to achieve a balance between membrane fluidity and some level of intrinsic curvature for cellular function (de Kroon et al., 2013). Thus, a constant MGDG to DGDG ratio may be preferred to one that changes dramatically due to stress (Boudière et al., 2014). It is plausible that maintenance of MGDG levels contributes to the chloroplast functionality (color retention) seen in 'Celebration' and 'Tifway' under chilling temperatures.

Phospholipid content at 0 DOT was $10 \%$ of total lipids across all cultivars (Table 1). Among the phospholipids, only PC, PE, and PG accounted for greater than $1 \%$ of total lipids. In their work on perennial ryegrass (Lolium perenne), Hoffman et al. (2010) reported freezing-tolerant accessions exhibited a greater proportion of phospholipids $\mathrm{PC}$ and $\mathrm{PG}$ and decreases in PA, PI, and PS when exposed to $2{ }^{\circ} \mathrm{C}$. This differs from the present study, which showed an inverse relationship between PC and PG (Table 2). Phophatidylglycerol (PG) is the major phospholipid in chloroplasts, and thylakoid membrane fluidity under chilling temperatures has been associated with PG unsaturation level (Wada and Murata, 2007). PG has been described as critical to maintenance of photosystem II and the D1 protein under high light and low temperature conditions (Kruse and Schmid, 1995; Wada and Murata, 2007). It is possible the light quantity achieved in the growth chamber during the present study was insufficient to induce osmotic stress typical of early frost conditions. Investigation of the chilling response under varying light regimes may be warranted to determine the importance of PG for bermudagrass chilling tolerance.

In response to chilling stress, PC and PE content generally increased for each cultivar in agreement with previous studies in cereal rye (Uemura and Steponkus, 1994; Table 1). 'Tahoma 31 ' contained the highest PE content at 14 DOT and greatest PC content at 42 DOT. Increases in PC content associated with cold acclimation have been reported to increase membrane stability and survival under freezing stress (Hoffman et al., 2010; Uemura and Steponkus, 1999; Welti et al., 2002). In contrast, greater PE concentration could contribute to a nonlamellar phase that would reduce membrane stability under 
Table 1. Membrane lipid class concentration on a mole percentage basis ( $\mathrm{mol} \%$ ) of three bermudagrass cultivars after exposure to 0,14 , and $42 \mathrm{~d}$ of chilling treatment (DOT) at $8 / 2{ }^{\circ} \mathrm{C}$ and $40 \mathrm{~d}$ of recovery (DOR) after $14 \mathrm{~d}$ under $17 / 3{ }^{\circ} \mathrm{C}, 7 \mathrm{~d}$ under $22 / 8{ }^{\circ} \mathrm{C}$, and $19 \mathrm{~d}$ under $27 / 14{ }^{\circ} \mathrm{C}$.

\begin{tabular}{|c|c|c|c|c|c|c|c|c|c|c|}
\hline \multirow[b]{2}{*}{ Time } & \multirow[b]{2}{*}{ Cultivar } & MGDG $^{z}$ & DGDG & $\mathrm{PC}$ & $\mathrm{PG}$ & $\overline{\mathrm{PE}}$ & PI & PA & PS & \multirow[b]{2}{*}{ DBI } \\
\hline & & \multicolumn{8}{|c|}{ 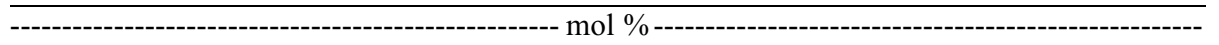 } & \\
\hline \multirow[t]{2}{*}{0 DOT } & Celebration & $68.2 \mathrm{a}^{\mathrm{y}}$ & $22.2 \mathrm{~g}$ & $4.3 \mathrm{f}$ & $2.8 \mathrm{c}$ & $1.6 \mathrm{f}$ & 0.60 bcd & $0.18 \mathrm{a}$ & $0.025 \mathrm{fg}$ & $5.16 \mathrm{f}$ \\
\hline & Tahoma 31 & $66.2 \mathrm{~b}$ & $23.4 \mathrm{f}$ & $4.8 \mathrm{de}$ & $3.3 \mathrm{a}$ & $1.8 \mathrm{e}$ & $0.52 \mathrm{de}$ & $0.13 b c$ & $0.026 \mathrm{ef}$ & $5.21 \mathrm{def}$ \\
\hline \multirow[t]{3}{*}{$14 \mathrm{DOT}$} & Celebration & $62.8 \mathrm{~d}$ & $26.8 \mathrm{~cd}$ & $5.1 \mathrm{~d}$ & $2.1 \mathrm{f}$ & $2.2 \mathrm{c}$ & $0.55 \mathrm{cde}$ & $0.09 \mathrm{c}$ & $0.026 \mathrm{ef}$ & $5.22 \mathrm{de}$ \\
\hline & Tahoma 31 & $60.5 \mathrm{e}$ & $27.9 \mathrm{bc}$ & $5.2 \mathrm{~d}$ & $2.6 \mathrm{de}$ & $2.8 \mathrm{ab}$ & $0.51 \mathrm{e}$ & $0.15 \mathrm{abc}$ & $0.019 \mathrm{~h}$ & 5.18 ef \\
\hline & Tifway & $64.0 \mathrm{~cd}$ & $25.9 \mathrm{~d}$ & $4.6 \mathrm{def}$ & $2.5 \mathrm{e}$ & $2.1 \mathrm{c}$ & $0.53 \mathrm{de}$ & $0.08 \mathrm{c}$ & $0.030 \mathrm{cde}$ & $5.31 \mathrm{ab}$ \\
\hline & Tahoma 31 & $55.2 \mathrm{~g}$ & $31.1 \mathrm{a}$ & $7.7 \mathrm{a}$ & $1.7 \mathrm{~g}$ & $2.9 \mathrm{a}$ & $0.55 \mathrm{cde}$ & $0.13 \mathrm{bc}$ & $0.025 \mathrm{fg}$ & $5.21 \mathrm{def}$ \\
\hline & Tifway & $59.2 \mathrm{ef}$ & $28.3 \mathrm{~b}$ & $6.5 \mathrm{c}$ & $1.8 \mathrm{~g}$ & $2.9 \mathrm{a}$ & $0.76 \mathrm{a}$ & $0.09 \mathrm{c}$ & $0.032 \mathrm{bcd}$ & $5.32 \mathrm{a}$ \\
\hline \multirow[t]{3}{*}{$40 \mathrm{DOR}$} & Celebration & $68.1 \mathrm{a}$ & $22.7 \mathrm{fg}$ & $4.3 \mathrm{f}$ & $2.7 \mathrm{de}$ & $1.5 \mathrm{f}$ & $0.62 \mathrm{bc}$ & $0.12 \mathrm{bc}$ & $0.037 \mathrm{ab}$ & $5.23 \mathrm{~d}$ \\
\hline & Tahoma 31 & $66.3 \mathrm{~b}$ & $23.5 \mathrm{f}$ & $4.7 \mathrm{de}$ & $3.1 \mathrm{~b}$ & $1.7 \mathrm{e}$ & $0.59 \mathrm{bcd}$ & $0.13 \mathrm{bc}$ & $0.035 \mathrm{bc}$ & $5.27 \mathrm{c}$ \\
\hline & Tifway & $65.4 \mathrm{c}$ & $24.7 \mathrm{e}$ & $4.5 \mathrm{ef}$ & $2.6 \mathrm{de}$ & $1.8 \mathrm{de}$ & $0.70 \mathrm{a}$ & $0.10 \mathrm{c}$ & $0.042 \mathrm{a}$ & $5.28 \mathrm{bc}$ \\
\hline Significance & Time $(\mathrm{T})$ & $* * *$ & $* * *$ & $* * *$ & $* * *$ & $* * *$ & $* * *$ & NS & $* * *$ & $* *$ \\
\hline
\end{tabular}

$\overline{{ }^{\mathrm{z}} \mathrm{MGDG}}=$ monogalactosyldiacylglycerol, $\mathrm{DGDG}=$ digalactosyldiacylglycerol, $\mathrm{PC}=$ phosphatidylcholine, $\mathrm{PG}=$ phosphatidylglycerol, $\mathrm{PE}=$ phosphatidylethanolamine, PI = phosphatidylinositol, PS = phosphatidylserine, PA = phosphatidic acid, DBI $=$ double bond index.

${ }^{\mathrm{y}}$ Means followed by the same letter in a column are not significantly different $(P \leq 0.05)$ according to Fisher's unadjusted $t$ test.

Ns, *,**,***Nonsignificant or significant $F$ test at the $0.05,0.01$, or $0.001 P$ level, respectively.

Table 2. Pearson's correlation coefficients for lipid class concentration within 'Celebration', 'Tahoma 31', and 'Tifway' bermudagrass leaves after exposure to 0,14 , and $42 \mathrm{~d}$ of chilling treatment at $8 / 2^{\circ} \mathrm{C}$ and $40 \mathrm{~d}$ of recovery after $14 \mathrm{~d}$ under $17 / 3{ }^{\circ} \mathrm{C}, 7 \mathrm{~d}$ under $22 / 8^{\circ} \mathrm{C}$, and $19 \mathrm{~d}$ under $27 / 14^{\circ} \mathrm{C}$.

\begin{tabular}{lccccrrrr}
\hline & MGDG $^{2}$ & DGDG & PC & PG & PE & PI & PS \\
\hline MGDG & & -0.986 & -0.898 & 0.776 & -0.922 & -0.104 & 0.209 \\
DGDG & $* * *$ & & 0.829 & -0.806 & 0.914 & 0.075 & -0.202 \\
PC & $* * *$ & $* * *$ & & -0.741 & 0.772 & 0.160 & -0.169 \\
PG & $* * *$ & $* * *$ & $* * *$ & & -0.746 & -0.227 & 0.105 \\
PE & $* * *$ & $* * *$ & $* * *$ & $* * *$ & & 0.131 \\
PI & NS & NS & NS & NS & NS & -0.107 & -0.296 \\
PS & NS & NS & NS & NS & $*$ & -0.052 \\
PA & NS & NS & NS & NS & NS & NS & 0.593 \\
\hline
\end{tabular}

${ }^{\mathrm{z}} \mathrm{MGDG}=$ monogalactosyldiacylglycerol, $\mathrm{DGDG}=$ digalactosyldiacylglycerol, $\mathrm{PC}=$ phosphatidylcholine, $\mathrm{PG}=$ phosphatidylglycerol, $\mathrm{PE}=$ phosphatidylethanolamine, $\mathrm{PI}=$ phosphatidylinositol, $\mathrm{PS}=$ phosphatidylserine, $\mathrm{PA}=$ phosphatidic acid.

NS, *, ***Nonsignificant or significant $F$ test at the 0.05 or $0.001 P$ level, respectively.

low temperature stress (Gruner et al., 1985). Others have reported that increased PE concentration was predominantly in the di-unsaturated form, which could combat the tendency of PE to produce a nonbilayer structure (Uemura and Steponkus, 1994; Welti et al., 2002). Zhang et al. (2009) similarly reported greater PC and PE in freezing-tolerant 'Meyer' zoysiagrass (Zoysia japonica) as compared with 'Cavalier' (Zoysia sp.). These results provide evidence that cold acclimation processes are occurring with potential positive effects on freezing tolerance but apparent negative effects on chilling tolerance.

Membrane lipid DBI's were affected by cultivar at 14 and 42 DOT and 40 DOR (Table 1). 'Tifway' demonstrated the highest DBI at 14 and 42 DOT (Table 1). The lack of a chilling-induced effect on DBI for other cultivars was surprising but may be an artifact of shifts in lipid class concentration. When data were normalized, the mean number of double bonds (nDBI) for each cultivar increased within most lipid classes, except PG (Table 3). For MGDG, the nDBI within 'Tifway' demonstrated the greatest increase from 0 to 42 DOT, which largely explains its greater overall DBI under chilling. The unsaturation level of membrane lipids influences the fluidity of the membrane which in turn influences the cell's ability to prevent cracking (Lyons and Raison, 1970). Chilling-sensitive plants have a greater proportion of saturated to unsaturated fatty acids when compared with chilling-tolerant plants (Lyons et al., 1964). Similar findings have been reported for stolon or rhizome tissue of freezing-tolerant cultivars for various turfgrass species (Cyril et al., 2002; Samala et al., 1998; Zhang et al., 2009). In the present study, the superior chilling tolerance of 'Tifway' may be related to unsaturation level of its membrane lipids, most notably in the chloroplast where galactolipids are predominant.

LiPIDS MULTIVARIATE aNALYSIS. Discriminant analysis was first conducted using cultivar as the grouping variable to identify lipids influencing the cultivar main effect. A stepwise summary revealed a substantial drop in the partial $R^{2}$ value after the first two lipids were entered. The error count for classification analysis using only these two lipids (DGDG 34:3 and DGDG 36:3) was zero, and adding more variables would not improve the classification power (Table 4). Each of these lipids demonstrated a highly significant cultivar main effect 
Table 3. Normalized double bond index (nDBI) of lipid classes in leaves from three bermudagrass cultivars after exposure to 0 , 14 , and $42 \mathrm{~d}$ of chilling treatment (DOT) at $8 / 2{ }^{\circ} \mathrm{C}$ and $40 \mathrm{~d}$ of recovery (DOR) after $14 \mathrm{~d}$ under $17 / 3{ }^{\circ} \mathrm{C}, 7 \mathrm{~d}$ under $22 / 8{ }^{\circ} \mathrm{C}$, and $19 \mathrm{~d}$ under $27 / 14{ }^{\circ} \mathrm{C}$.

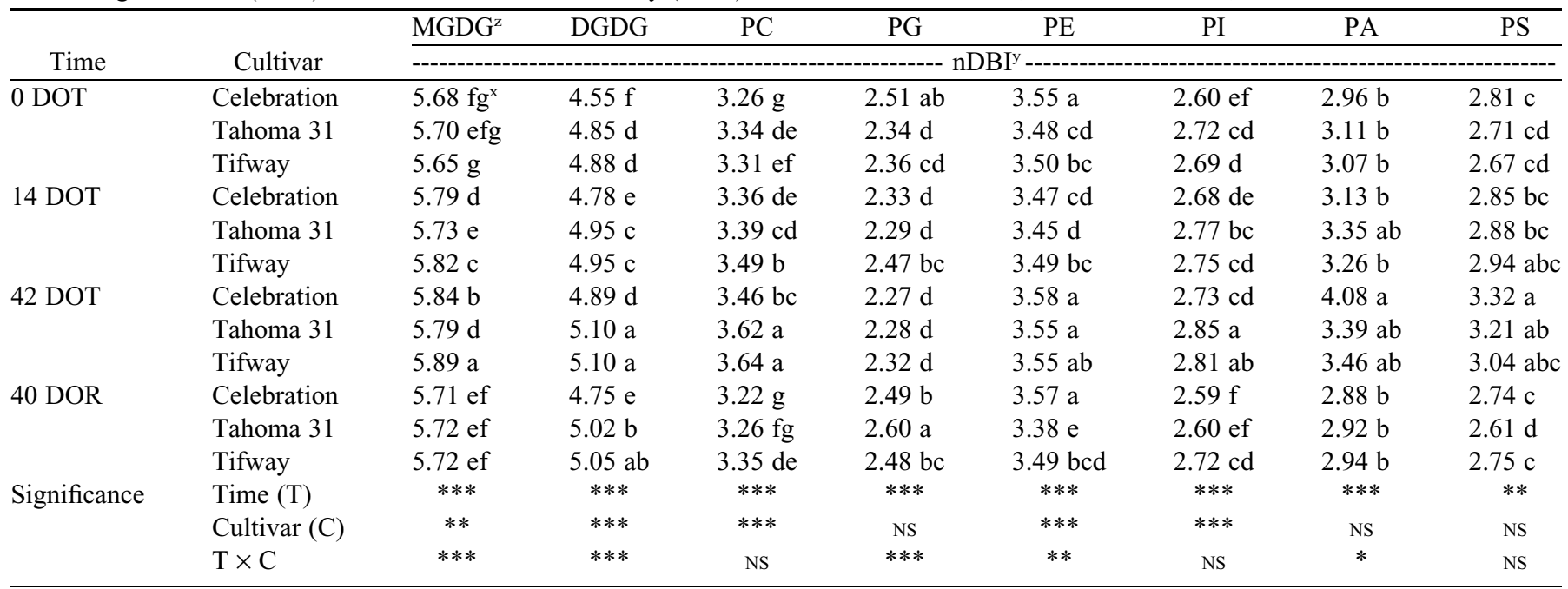

${ }_{\mathrm{z}} \mathrm{MGDG}=$ monogalactosyldiacylglycerol, $\mathrm{DGDG}=$ digalactosyldiacylglycerol, $\mathrm{PC}=$ phosphatidylcholine, $\mathrm{PG}=$ phosphatidylglycerol, $\mathrm{PE}=$ phosphatidylethanolamine, $\mathrm{PI}=$ phosphatidylinositol, $\mathrm{PS}=$ phosphatidylserine, $\mathrm{PA}=$ phosphatidic acid.

$\mathrm{y}_{\mathrm{nDBI}}=$ normalized double bond index $(\mathrm{nDBI})$, which was calculated as the number of double bonds in an individual lipid multiplied by its concentration (\% mol basis) and divided by the concentration of the lipid class. Data are presented as the mean nDBI for each time by cultivar combination.

${ }^{\mathrm{x}}$ Means followed by the same letter in a column are not significantly different $(P \leq 0.05)$ according to Fisher's unadjusted $t$ test.

NS, *,*****Nonsignificant or significant $F$ test at the $0.05,0.01$, or $0.001 P$ level, respectively.

Table 4. Classification error rates of three stepwise discriminant analysis approaches using lipid composition of bermudagrass leaves to identify three bermudagrass cultivars (Celebration, Tahoma 31, Tifway), four sampling times, or 12 cultivar-by-time pairs.

\begin{tabular}{|c|c|c|c|c|c|}
\hline \multicolumn{2}{|c|}{ Approach 1: Cultivar (C) } & \multicolumn{2}{|c|}{ Approach 2: Time $^{\mathrm{z}}(\mathrm{T})$} & \multicolumn{2}{|c|}{ Approach 3: $\mathrm{C} \times \mathrm{T}$} \\
\hline $\operatorname{Lipid}^{y}$ & Error rate $^{\mathrm{x}}(\%)$ & Lipid & Error rate $(\%)$ & Lipid & Error rate $(\%)$ \\
\hline DGDG 34:3 & 23 & PC 36:5 & - & PC $34: 3$ & - \\
\hline DGDG $36: 3$ & 0 & PG 32:1 & 一 & DGDG $34: 3$ & 20 \\
\hline & & MGDG 36:4 & 8 & DGDG 36:3 & 12 \\
\hline & & PS $40: 3$ & 7 & MGDG $34: 3$ & 3 \\
\hline & & PS 42:3 & 5 & PC 34:1 & 2 \\
\hline & & PG 34:2 & 2 & MDGD 36:5 & 0 \\
\hline
\end{tabular}

${ }^{\mathrm{z}}$ Time included sampling dates at 0,14 , and $42 \mathrm{~d}$ of chilling treatment at $8 / 2{ }^{\circ} \mathrm{C}$ and $40 \mathrm{~d}$ of recovery after $14 \mathrm{~d}$ under $17 / 3{ }^{\circ} \mathrm{C}, 7 \mathrm{~d}$ under $22 / 8{ }^{\circ} \mathrm{C}$, and $19 \mathrm{~d}$ under $27 / 14{ }^{\circ} \mathrm{C}$.

${ }^{\mathrm{y}}$ Lipids are described using the species name and lipid number. DGDG $=$ digalactosyldiacylglycerol, $\mathrm{PC}=$ phosphatidylcholine, $\mathrm{PG}=$ phosphatidylglycerol, $\mathrm{MGDG}=$ monogalactosyldiacylglycerol, $\mathrm{PS}=$ phosphatidylserine. Lipid numbers for the corresponding lipid species have the form $\mathrm{C}: \mathrm{D}$ where $\mathrm{C}$ is the number of carbon atoms in the fatty acids and $\mathrm{D}$ is the number of double bonds in the fatty acids. ${ }^{\mathrm{x}}$ Error rates indicate the ability of the model to discriminate between cultivars, sampling times, or cultivar by time pairs. A lower error rate indicates better accuracy. Identified lipids were determined by the stepwise model as most readily discriminating between factor levels.

corresponding to consistently greater concentrations in Celebration as compared with other cultivars (Table 5). The greater saturation level of these acyl groups did not appear to influence the chilling tolerance of 'Celebration' and may simply be indicative of common bermudagrass in general, although no such response was found in a previous report on bermudagrass lipid composition under drought stress ( $\mathrm{Su}$ et al., 2013). 'Tifway' demonstrated a lower DGDG 36:3 content than 'Tahoma 31', which would contribute to greater unsaturation of fatty acids in the chloroplast and presumably superior tolerance to chilling stress.

A second discriminant analysis was conducted using only time as the grouping variable to determine the shared effect of chilling stress on lipid profiles across cultivars. Based on the stepwise summary, six lipids were selected for the analysis: PC 36:5, PG 32:1, MGDG 36:4, PS 40:3, PS 42:3, and PG 34:2 (Table 4). The first two lipids (PC 36:5 and PG $32: 1)$ demonstrated highly significant time main effects corresponding to greater PC $36: 5$ and reduced PG 32:1 under chilling (Table 6). Previous study in Arabidopsis thaliana found a strong relationship between the concentration of di-saturated (32:0) and the $16: 0$ to $16: 1$ (3t) species of PG and the chilling sensitivity of plants (Murata, 1983; Wada and Murata, 2007). The present study did not find such a connection; rather, 'Celebration' demonstrated the greatest PG 32:0, while 'Tifway' and 'Tahoma 31' were similar at each date. For MGDG 36:4, PS 40:3, and PG 34:2, the time main effect was highly significant but varied with cultivar. For example, MGDG 36:4 concentration declined in each cultivar due to chilling stress, but at a greater rate in Tifway as compared with either Celebration or Tahoma 31 (Table 5).

The final discriminant analysis used 12 combinations of cultivar and time to identify lipids that contributed to describing the time by cultivar interaction. Six lipids were selected based on partial $R^{2}$ values and classification error rate: PC 34:3, DGDG 34:3, DGDG 36:3, MGDG 34:3, PC 34:1, and MGDG 36:5 (Table 4). Two of these lipids (DGDG 34:3 and DGDG 36:3) were previously identified as discriminating for the 
Table 5. Concentration on a mole percentage basis ( $\mathrm{mol} \%$ ) of selected galactolipids in leaves of three bermudagrasses after exposure to 0 , 14 , and $42 \mathrm{~d}$ of chilling treatment (DOT) at $8 / 2{ }^{\circ} \mathrm{C}$ and $40 \mathrm{~d}$ of recovery (DOR) after $14 \mathrm{~d}$ under $17 / 3{ }^{\circ} \mathrm{C}, 7 \mathrm{~d}$ under $22 / 8{ }^{\circ} \mathrm{C}$, and $19 \mathrm{~d}$ under $27 / 14{ }^{\circ} \mathrm{C}$.

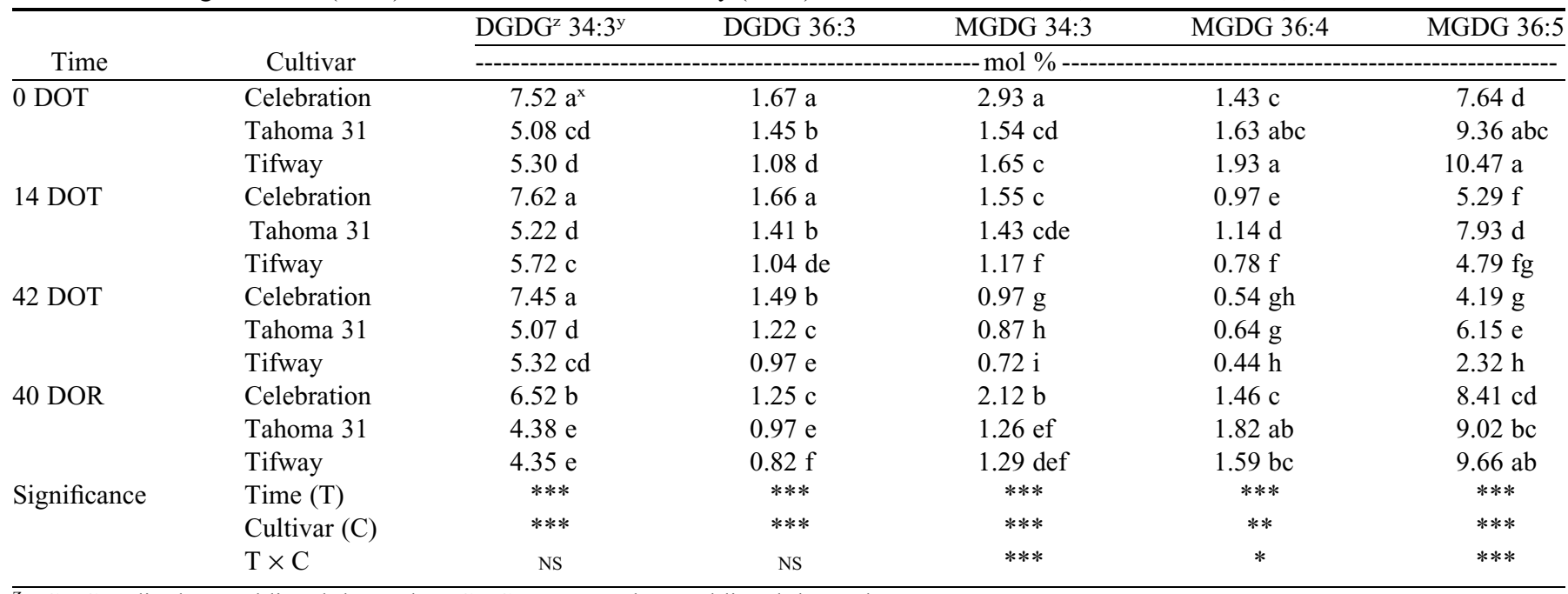

${ }^{\mathrm{z}} \mathrm{DGDG}=$ digalactosyldiacylglycerol, $\mathrm{MGDG}=$ monogalactosyldiacylglycerol.

${ }^{\mathrm{y}}$ Lipid numbers for the corresponding lipid species have the form $\mathrm{C}: \mathrm{D}$ where $\mathrm{C}$ is the number of carbon atoms in the fatty acids and $\mathrm{D}$ is the number of double bonds in the fatty acids.

${ }^{\mathrm{x}}$ Means followed by the same letter in a column are not significantly different $(P \leq 0.05)$ according to Fisher's unadjusted $t$ test.

NS, *,**,**Nonsignificant or significant $F$ test at the $0.05,0.01$, or $0.001 P$ level, respectively.

Table 6. Concentration on a mole percentage basis $(\% \mathrm{~mol})$ of selected phospholipids in leaves of three bermudagrasses after exposure to 0 , 14 , and $42 \mathrm{~d}$ of chilling treatment (DOT) at $8 / 2{ }^{\circ} \mathrm{C}$ and $40 \mathrm{~d}$ of recovery (DOR) after $14 \mathrm{~d}$ under $17 / 3{ }^{\circ} \mathrm{C}, 7 \mathrm{~d}$ under $22 / 8{ }^{\circ} \mathrm{C}$, and $19 \mathrm{~d}$ under $27 / 14^{\circ} \mathrm{C}$

\begin{tabular}{|c|c|c|c|c|c|c|c|c|}
\hline \multirow[b]{2}{*}{ Time } & \multirow[b]{2}{*}{ Cultivar } & $\mathrm{PC}^{\mathrm{z}} 34: 1^{\mathrm{y}}$ & PC 34:3 & PC 36:5 & PG 32:1 & PG 34:2 & PS 40:3 & PS 42:3 \\
\hline & & \multicolumn{7}{|c|}{ 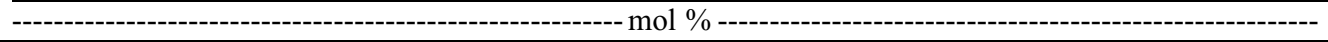 } \\
\hline \multirow[t]{2}{*}{0 DOT } & Celebration & $0.05 \mathrm{e}^{\mathrm{x}}$ & $0.87 \mathrm{f}$ & $0.68 \mathrm{~g}$ & $0.30 \mathrm{bc}$ & $0.56 \mathrm{~b}$ & $0.0012 \mathrm{fg}$ & $0.0057 \mathrm{bc}$ \\
\hline & Tahoma 31 & $0.03 \mathrm{f}$ & $0.91 \mathrm{f}$ & $0.84 \mathrm{~cd}$ & $0.28 \mathrm{bc}$ & $0.52 \mathrm{bc}$ & $0.0017 \mathrm{def}$ & $0.0024 \mathrm{gh}$ \\
\hline \multirow[t]{2}{*}{14 DOT } & Celebration & $0.11 \mathrm{ab}$ & 0.97 ef & $0.93 \mathrm{bc}$ & $0.21 \mathrm{~d}$ & $0.40 \mathrm{~d}$ & $0.0034 \mathrm{ab}$ & $0.0066 \mathrm{ab}$ \\
\hline & Tahoma 31 & $0.06 \mathrm{e}$ & $1.22 \mathrm{c}$ & $0.97 \mathrm{~b}$ & $0.16 \mathrm{ef}$ & $0.75 \mathrm{a}$ & $0.0009 \mathrm{fg}$ & $0.0043 \mathrm{cde}$ \\
\hline \multirow{2}{*}{$42 \mathrm{DOT}$} & Tahoma 31 & $0.11 \mathrm{a}$ & $2.33 \mathrm{a}$ & $1.51 \mathrm{a}$ & $0.12 \mathrm{~g}$ & $0.48 \mathrm{c}$ & $0.0040 \mathrm{a}$ & $0.0050 \mathrm{~cd}$ \\
\hline & Tifway & $0.08 \mathrm{c}$ & $1.88 \mathrm{~b}$ & $1.40 \mathrm{a}$ & $0.14 \mathrm{fg}$ & $0.56 \mathrm{~b}$ & $0.0005 \mathrm{~g}$ & $0.0039 \mathrm{def}$ \\
\hline \multirow[t]{3}{*}{40 DOR } & Celebration & $0.05 \mathrm{e}$ & $0.94 \mathrm{f}$ & $0.62 \mathrm{~h}$ & $0.39 \mathrm{a}$ & $0.64 \mathrm{ab}$ & 0.0022 cde & 0.0034 efg \\
\hline & Tahoma 31 & $0.06 \mathrm{e}$ & $0.70 \mathrm{~g}$ & $0.72 \mathrm{fg}$ & $0.36 \mathrm{a}$ & $0.46 \mathrm{c}$ & $0.0036 a b$ & $0.0036 \mathrm{defg}$ \\
\hline & Tifway & $0.09 \mathrm{~b}$ & $1.13 \mathrm{de}$ & $0.75 \mathrm{ef}$ & $0.32 \mathrm{~b}$ & $0.46 \mathrm{c}$ & $0.0023 \mathrm{~cd}$ & $0.0080 \mathrm{a}$ \\
\hline Significance & Time $(\mathrm{T})$ & $* * *$ & $* * *$ & $* * *$ & $* * *$ & $* * *$ & $* * *$ & $* * *$ \\
\hline
\end{tabular}

${ }^{\mathrm{z} C}=$ phosphatidylcholine, $\mathrm{PG}=$ phosphatidylglycerol, $\mathrm{PS}=$ phosphatidylserine.

${ }^{\mathrm{y}}$ Lipid numbers for the corresponding lipid species have the form $\mathrm{C}: \mathrm{D}$ where $\mathrm{C}$ is the number of carbon atoms in the fatty acids and $\mathrm{D}$ is the number of double bonds in the fatty acids.

${ }^{\mathrm{x}}$ Means followed by the same letter in a column are not significantly different $(P \leq 0.05)$ according to Fisher's unadjusted $t$ test.

NS, **,***Nonsignificant or significant $F$ test at the $0.05,0.01$, or $0.001 P$ level, respectively.

cultivar main effect. The remaining four lipids contributed to classification of individual cultivar by time combinations that were not strongly evident in the previous two analyses. 'Tahoma 31' contained the least PC 34:1 at 0 DOT but the most PC 34:1 and PC 34:3 at 42 DOT (Table 6). The PC 34:1 content at 0 DOT was greatest in 'Tifway' and showed an initial decrease in this cultivar at 14 DOT not seen in the other two cultivars. From 0 to 42 DOT, 'Tifway' also showed the largest decrease in MGDG 36:5 content among cultivars (Table 5).
This finding is consistent with the greater nDBI for 'Tifway' within the MGDG lipid class (Table 3).

The present study provides evidence that some chillinginduced changes in lipid composition (e.g., increasing PC and declining MGDG content) of leaves may promote freezing tolerance of bermudagrass but negatively affect chilling tolerance. Similarly, the unsaturation level of plastid lipids, particularly MGDG, seems likely to enhance chilling tolerance and therefore fall color retention of bermudagrass. It is important to 
note that the present study exclusively measured lipid composition of leaves, the organ most important for chilling tolerance, and did not quantify lipid composition of stolons or rhizomes, the organs most important for freezing tolerance. In a previous report, chilling temperatures resulted in 'Tifgreen' having greater reducing and nonreducing sugars than 'Midiron' in leaves but the reverse in stems, stolons, and rhizomes (White and Schmidt, 1989). It is unknown whether chilling-induced changes in lipid composition similarly varies with cultivar and organ.

In addition to lipid composition, there are several other attributes of plants (e.g., protein synthesis, carbohydrate mobilization, and stomatal control) that could be influencing low temperature stress response in bermudagrass (Munshaw et al., 2006; White and Schmidt, 1989; Zhang et al., 2006). Follow-up studies are needed to document how these additional attributes vary among the selected cultivars under chilling stress. This study also did not address the role of light intensity or photoperiod on chilling response. There is evidence that increasing photoperiod alone can induce measureable growth in bermudagrass even under low light intensity and decreasing temperature (Esmaili and Salehi, 2012; Sinclair et al., 2003). The use of artificial light sources has become increasingly popular for stadium fields and the relative importance of light or temperature on fall color retention and lipid composition warrants additional study.

\section{Conclusion}

A growth chamber experiment was used to simulate chilling stress associated with late autumn temperatures in Oklahoma. The cultivar showing the poorest chilling tolerance ('Tahoma 31') also demonstrated the best post-dormancy regrowth. Prolonged exposure to chilling stress generally increased DGDG and PC content and decreased MGDG content with 'Tahoma 31', showing the greatest increase in PC and decrease in MGDG. Unsaturation of galactolipids, particularly MGDG, in chloroplasts appears to be an important mechanism for chilling tolerance of 'Tifway' but not necessarily for 'Celebration'. Multivariate discriminant analysis identified six individual lipid species that contributed most to the cultivar response to chilling and may contribute to more efficient selection and improvement of germplasm for the chilling tolerance trait in bermudagrass.

\section{Literature Cited}

Anderson, J.A., C.M. Taliaferro, and D.L. Martin. 1993. Evaluating freeze tolerance of bermudagrass in a controlled environment. HortScience 28:955.

Boudière, L., M. Michaud, D. Petroutsos, F. Rébeillé, D. Falconet, O. Bastien, S. Roy, G. Finazzi, N. Rolland, J. Jouhet, and M.A. Block. 2014. Glycerolipids in photosynthesis: Composition, synthesis and trafficking. Biochim. Biophys. Acta 1837:470-480.

Bruce, B.D. 1998. The role of lipids in plastid protein transport. Plant Mol. Biol. 38:223-246.

Cyril, J., G.L. Powell, R.R. Duncan, and W.V. Baird. 2002. Changes in membrane polar lipid fatty acids of seashore paspalum in response to low temperature exposure. Crop Sci. 42:2031-2037.

de Kroon, A.I.P.M., P.J. Rijken, and C.H. de Smet. 2013. Checks and balances in membrane phospholipid class and acyl chain homeostasis, the yeast perspective. Prog. Lipid Res. 52:374-394.

Devaiah, S.P., M.R. Roth, E. Baughman, M. Li, P. Tamura, R. Jeannotte, R. Welti, and X. Wang. 2006. Quantitative profiling of polar glycerolipid species and the role of phospholipase D $\alpha 1$ in defining the lipid species in Arabidopsis tissues. Phytochemistry 67:1907-1924.

Douce, R. and J. Joyard. 1990. Biochemistry and function of the plastid envelope. Annu. Rev. Cell Biol. 6:173-216.

Esmaili, S. and H. Salehi. 2012. Effects of temperature and photoperiod on postponing bermudagrass (Cynodon dactylon [L.] Pers.) turf dormancy. J. Plant Physiol. 169:851-858.

Fontanier, C. and K. Steinke. 2017. Competitiveness of the three warm-season turfgrass during spring transition of overseeded turfs. Intl. Turfgrass Res. J. 13:1-9.

Gatschet, M.J., C.M. Taliaferro, J.A. Anderson, D.R. Porter, and M.P. Anderson. 1994. Cold acclimation and alterations in protein synthesis in bermudagrass crowns. J. Amer. Soc. Hort. Sci. 119: 477-480.

Gruner, S.M., P.R. Cullis, M.J. Hope, and C.P.S. Tilcock. 1985. Lipid polymorphisms: The molecular basic of nonbilayer phases. Annu. Rev. Biophys. Biophys. Chem. 14:211-238.

Hoffman, L., M. DaCosta, J.S. Ebdon, and E. Watkins. 2010. Physiological changes during cold acclimation of perennial ryegrass accessions differing in freeze tolerance. Crop Sci. 50:1037-1047.

Kimball, S.L. and F.B. Salisbury. 1973. Ultrastructural changes of plants exposed to low temperatures. Amer. J. Bot. 60:1028-1033.

Kruse, O. and G.H. Schmid. 1995. The role of phosphatidylglycerol as a functional effector and membrane anchor of the D1-core peptide from photosystem II-particles of the cyanobaterium Oscillatoria chalybea. Z. Naturforsch. C 50:380-390.

Lyons, J.M., T.A. Wheaton, and H.K. Pratt. 1964. Relationship between the physical nature of mitochondrial membranes and chilling sensitivity in plants. Plant Physiol. 39:262-268.

Lyons, J.M. and J.K. Raison. 1970. Oxidative activity of mitochondria isolated from plant tissues sensitive and resistant to chilling injury. Plant Physiol. 45:386-389.

Munshaw, G.C., E.H. Ervin, C. Shang, S.D. Askew, X. Zhang, and R.W. Lemus. 2006. Influence of late-season iron, nitrogen, and seaweed extract on fall color retention and cold tolerance of four bermudagrass cultivars. Crop Sci. 46:273-283.

Murata, N. 1983. Molecular species composition of phosphatidylglycerols from chilling-sensitive and chilling-resistant plants. Plant Cell Physiol. 23:81-86.

National Turfgrass Evaluation Program (NTEP). 1997. Final Report NTEP No. 97-9. 1992 National Bermudagrass Test. 4 Sept. 2018. $<$ http://www.ntep.org/reports/bg92/bg92_97-9f/bg92_97-9f.htm>.

National Turfgrass Evaluation Program (NTEP). 2013. Final Report NTEP No. 13-10. 2007 National Bermudagrass Test. 4 Sept. 2018. $<$ http://www.ntep.org/reports/bg07/bg07_13-10f/bg07_13-10f.htm>.

National Turfgrass Evaluation Program (NTEP). 2014. Progress Report NTEP No. 15-2. 2013 National Bermudagrass Test. 4 Sept. 2018. <http://ntep.org/reports/bg13/bg13_15-2/bg13_15-2.htm>.

Oklahoma Mesonet. 2015. Climate. 30 Aug. 2018. <http://www. mesonet.org.

Raison, J.K. and G.R. Orr. 1990. Proposals for a better understanding of the molecular basis of chilling injury, p. 145-164. In: CY Wang (ed.). Chilling injury of horticultural crops. CRC Press, Boca Raton, FL.

Samala, S., J. Yan, and W. Baird. 1998. Changes in polar lipid fatty acid composition during cold acclimation in 'Midiron' and 'U3' bermudagrass. Crop Sci. 38:188-195.

Schiavon, M., S. Macolino, B. Leinauer, and U. Ziliotto. 2016. Seasonal changes in carbohydrate and protein content of seeded bermudagrasses and their effect on spring green-up. J. Agron. Crop Sci. 202:151-160.

Sinclair, T.R., J.D. Ray, P. Mislevy, and L.M. Premazzi. 2003. Growth of subtropical forage grasses under extended photoperiod during short day length months. Crop Sci. 43:618-623.

Su, K., D.J. Bremer, R. Jeannotte, R. Welti, and C. Yang. 2009. Membrane lipid composition and heat tolerance in cool-season turfgrasses, including a hybrid bluegrass. J. Amer. Soc. Hort. Sci. 134:511-520. 
Su, K., J.Q. Moss, G. Zhang, Y. Wu, and D.L. Martin. 2013. Membrane lipid composition and drought tolerance in bermudagrass. Intl. Turfgrass Soc. Res. J. 12:445-452.

Uemura, M. and P.L. Steponkus. 1994. A contrast of the plasma membrane lipid composition of oat and rye leaves in relation to freezing tolerance. Plant Physiol. 104:479-496.

Uemura, M. and P.L. Steponkus. 1997. Effect of cold acclimation on the lipid composition of the inner and outer membrane of the chloroplast envelope isolated from rye leaves. Plant Physiol. 114:1493-1500.

Uemura, M. and P.L. Steponkus. 1999. Cold acclimation in plants: Relationship between the lipid composition and the cryostability of the plasma membrane. J. Plant Res. 112:245-254.

Wada, H. and N. Murata. 2007. The essential role of phosphatidylglycerol in photosynthesis. Photosynth. Res. 92:205-215.

Welti, R., L. Weiqi, Y. Sang, H. Biesiada, H. Zhou, C.B. Rajashekar, T.D. Williams, and X. Wang. 2002. Profiling membrane lipids in plant stress responses-Role of phospholipase D $\alpha$ in freezinginduced lipid changes in Arabidopsis. J. Biol. Chem. 277:3199432002 .

White, R.H. and R.E. Schmidt. 1989. Bermudagrass response to chilling temperatures as influenced by iron and benzyladenine. Crop Sci. 29:768-773

Zhang, Q., J. Fry, C. Rajashekar, D. Bremer, and M. Engelke. 2009. Membrane polar lipid changes in zoysiagrass rhizomes and their potential role in freezing tolerance. J. Amer. Soc. Hort. Sci. 124:322328.

Zhang, X., E.H. Ervin, and A.J. LaBranche. 2006. Metabolic defense of seeded bermudagrass during acclimation to freezing stress. Crop Sci. 46:2598-2605.

Zhang, X., K. Wang, and E.H. Ervin. 2008. Bermudagrass freezing tolerance associated with abscisic acid metabolism and dehydrin expression during cold acclimation. J. Amer. Soc. Hort. Sci. 133: $542-550$. 